\title{
Development of Fluid Viscosity Coefficient Apparatus Based On jetAudio and Subtitle Edit
}

\author{
Haris Rosdianto ${ }^{1}$, Emi Sulistri ${ }^{2}$ \\ STKIP Singkawang, Indonesia ${ }^{1,2}$ \\ harisrosdianto@yahoo.com ${ }^{1}$, sulistriemi@gmail.com²
}

Received: December $7^{\text {th }}, 2019$. Revised: January $3^{\text {th }}, 2020$. Accepted: January $5^{\text {th }}, 2020$

\author{
Keywords : \\ Apparatus; Viscosity \\ Coefficient; jetAudio; Subtitle \\ Edit
}

\begin{abstract}
The purpose of this research was to develop a fluid viscosity coefficient apparatus using computer application that is easily obtained and used, namely jetAudio and Subtitle Edit software. The research was conducted at Physics laboratory in STKIP Singkawang and 5 secondary schools in Singkawang City. The feasibility level of this apparatus is known through validation by experts. Validation was carried out by 3 physics lecturers. The results of the validation stage were used for user tests by 10 STKIP Singkawang students. From the results of the analysis obtained 1) the results of validation by tool experts amounted to $91.1 \%$ which were interpreted very good, 2) the results of validation by material and content experts amounted to $91.9 \%$ which were interpreted very good, and 3 ) the results of user tests conducted by students showed the percentage of responses at $71.35 \%$ which was interpreted good. Thus the apparatus is feasible to use and can be an alternative in physics learning that can improve students' skills and conceptual understanding.
\end{abstract}

\section{INTRODUCTION}

Practicum is an important part in learning physics, being able to train students' process skills and thinking skills [1-2]. Along with the development of computer technology, many practicum activities that utilize these technology applications to facilitate in getting more accurate data [1]. One of the practicum activities is practicum to determine the fluid viscosity coefficient [3-8).

When the ball dropped into a fluid, first it moves accelerated under the influence of gravity, then slowing down until the ball moves at a constant speed and finally stops at the bottom of the fluid [2]. This is because, beside experienced buoyancy and gravity, the ball also experienced friction between the surface of the ball and the fluid caused by the viscosity of the fluid [9]. The viscosity generated by the cohesive forces between the molecules of the liquid and is a measure of viscosity of a fluid which is quantitatively expressed by the coefficient of viscosity $\eta$ [1]. The greater the viscosity of a fluid, the more difficult an object moves in it [10]. 
Various methods can be used in determining the fluid viscosity coefficient. One that can be used is the falling ball method. First, the velocity of the ball will increase. But later, the ball will experience terminal velocity, where the object's gravity is equal to the amount between Archimedes and Stoke's force. Because of that, determining the value of viscosity begins with determining the terminal velocity [11].

Shanti used two coils as detection sensor to determining the viscosity of lubricant [6]. The two coils are connected to the oscilloscope and the results are processed using freewave 3 software. Terminal velocity of the ball can be determined by calculating the gradient from the graph of distance against time. Hantoro \& Suharno used Tracker video analysis software to determining the viscosity of cooking oil [4]. Ramadhan et al used UGN3503 hall effect sensor as an iron ball detection sensor as it passes through the fluid and causes the magnetic field of this sensor to change because the sensor is blocked by an iron ball magnet, so the magnetic field changed to output voltage [8]. Determination of viscosity is mostly done to find alternative methods that are easily obtained and used, and have better accuracy compared to experiments using stopwatch.

Based on the previous research, the purpose of this research was to develop an alternative media for learning about viscosity materials more thoroughly, namely by using jetAudio [12] and Subtitle Edit [13]. jetAudio is used to record magnetic traces when a magnetic ball passes through coils on a tube, while the Subtitle Edit is used to determine the ball's falling time between two coils based on jetAudio recording data. It is also hoped that the apparatus that have been developed can be carried out in schools so that it can be used as an alternative in learning activities. It also can train students to work scientifically, and help understanding the basic concepts of viscosity.

\section{METHOD}

This research begins by establishing that the fluid viscosity coefficient apparatus can be developed in the aspect of falling object data, by using jetAudio software and Subtitle Edit. Then the feasibility test of the apparatus is carried out through validation by experts. Validation was carried out by three lecturers. After being revised, a user trial was conducted by 10 students of the STKIP Singkawang physics education study program.

Data from the the feasibility test results and the user trials results are converted into scores with the provisions as in the following table 1.

Table 1. Convert scoring to numeric form

\begin{tabular}{cc}
\hline Category & Score \\
\hline Very Good & 4 \\
Good & 3 \\
Fair & 2 \\
Poor & 1 \\
\hline
\end{tabular}

To calculate the average score of each criterion, the following equation is taken:

$$
\bar{x}=\frac{\sum x}{n}
$$

Where:

$\bar{x}=$ the average score for each aspect

$\sum x=$ the total score of each aspect

$n \quad=\quad$ the number of respondent

Data obtained from the apparatus validation and user tests results were changed into a scale of 
four. Reference on changing the score to a scale of four can be seen in the following table 2 .

Table 2. Convert scores to four scale values

\begin{tabular}{ccc}
\hline no & Average range & Criteria \\
\hline 1 & $\mathrm{Mi}+1,5 \mathrm{SDi} \leq \mathrm{X} \leq \mathrm{Mi}+3,0 \mathrm{Sdi}$ & Very Good \\
2 & $\mathrm{Mi}+0 \mathrm{SDi} \leq \mathrm{X} \leq \mathrm{Mi}+1,5 \mathrm{SDi}$ & Good \\
3 & $\mathrm{Mi}-1,5 \mathrm{SDi} \leq \mathrm{X} \leq \mathrm{Mi}+0 \mathrm{SDi}$ & Fair \\
4 & $\mathrm{Mi}-3,0 \mathrm{SDi} \leq \mathrm{X} \leq \mathrm{Mi}-1,5 \mathrm{SDi}$ & Poor \\
\hline
\end{tabular}

Where:

X : $\quad$ the actual score

Mi : the average ideal score

: $\quad 1 / 2$ (highest ideal score + lowest ideal score)

SDi : $\quad$ The standard deviation of ideal score

: $\quad$ 1/6 (highest ideal score - lowest ideal score)

\section{RESULTS AND DISCUSSIONS}

The development research is based on the limitations of the apparatus in determining the fluid viscosity coefficient in secondary schools. The limitation lies in the technique of recording the travel time of a ball falling inside a tube. So with this, students are expected to understand the Stoke's Law and determine the fluid viscosity coefficient. The development carried out in this research is shown in figure 1 .

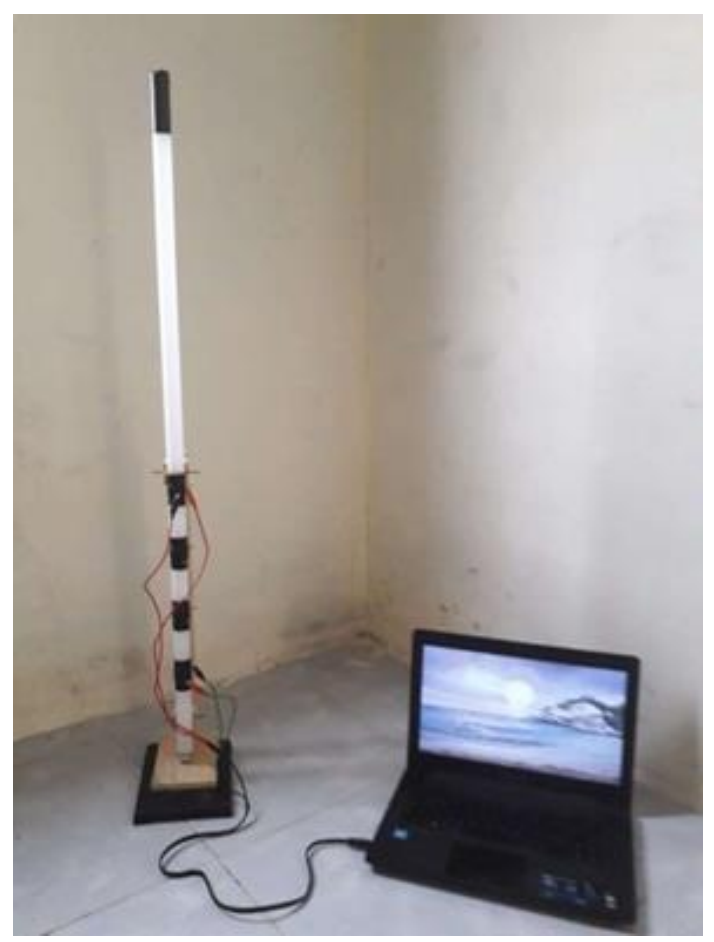

Fig 1. The Development of Apparatus for determining fluid viscosity

The components of the apparatus that have been developed are as follows:

1. A computer that has JetAudio software and Subtitle Edit installed as time data sampling.

2. Tube made from neon lights. 
3. Coils with adjustable spacing.

4. Cables that connect the coil to the computer.

5. A magnetic ball used as a falling object

From validation by tool expert, an average validation result of $91.1 \%$ was obtained which was interpreted very good and can be seen in following figure 2 .

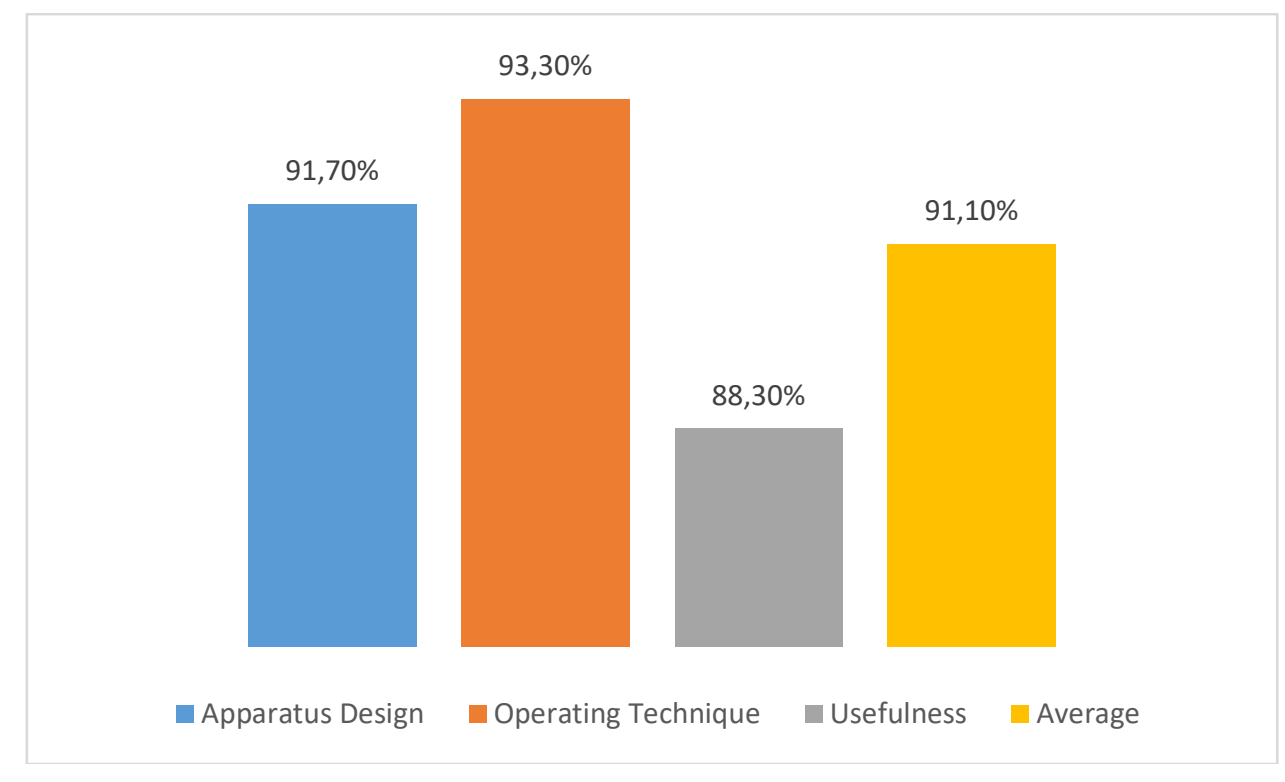

Fig 2. Tool Expert Validation Results

From validation by media and content experts, an average validation result of $91.9 \%$ was obtained which was interpreted very good and can be seen in following figure 3 .

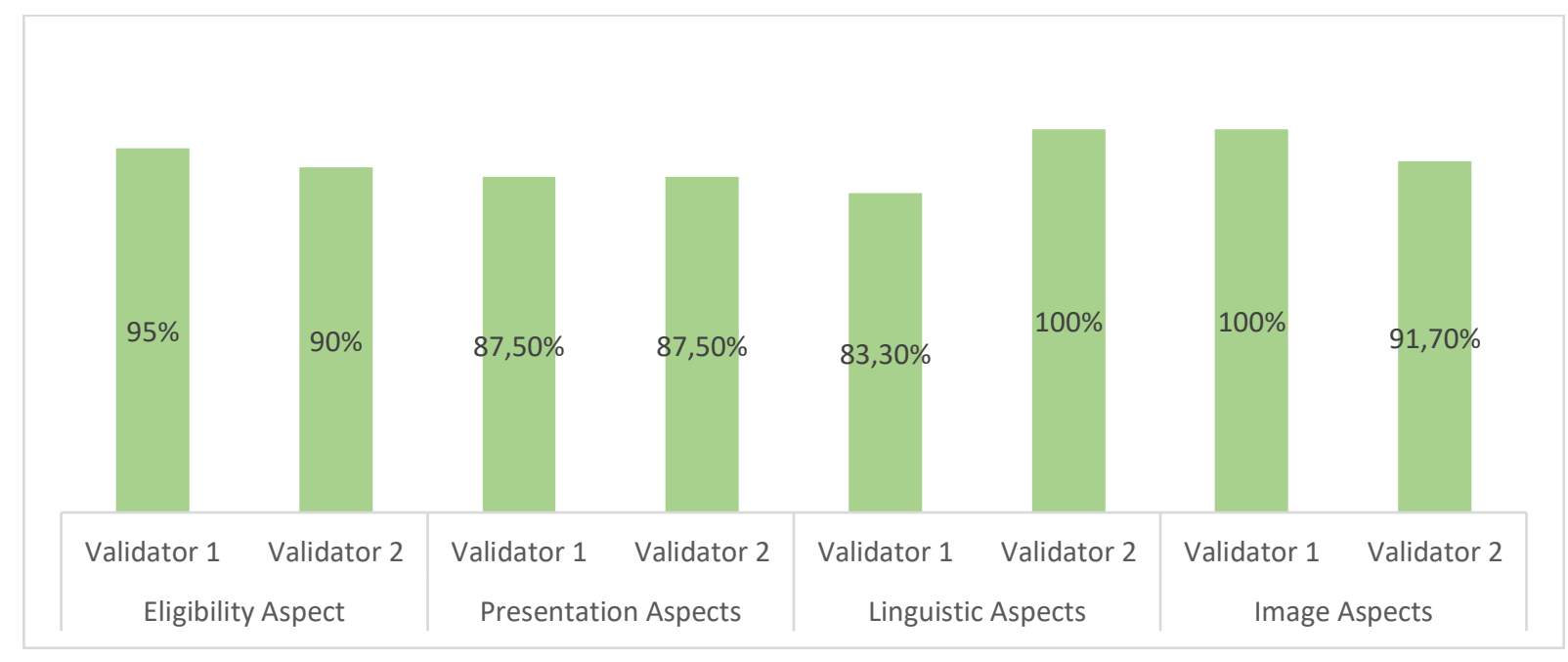

Fig 3. Media and Content Expert Validation Results

User tests were conducted by ten physics students at STKIP Singkawang. This stage is intended to determine the student's response after conducting the fluid viscosity coefficient experiment by using the apparatus that were developed. Students fill out evaluation sheet with 12 statements. The percentage for overall student responses in user trials was $71.35 \%$ in good criteria. The user test results are described in the following table 3. 
Table 3. User Test Validation Data Results

\begin{tabular}{|c|c|c|c|c|c|c|c|c|c|c|c|c|}
\hline \multirow{2}{*}{ Statement } & \multicolumn{10}{|c|}{ Students } & \multirow{2}{*}{$\sum$ Score } & \multirow{2}{*}{$\%$ Idea } \\
\hline & 1 & 2 & 3 & 4 & 5 & 6 & 7 & 8 & 9 & 10 & & \\
\hline 1 & 3 & 3 & 3 & 3 & 4 & 3 & 3 & 4 & 3 & 3 & 32 & \multirow{12}{*}{71.35} \\
\hline 2 & 3 & 3 & 3 & 3 & 4 & 3 & 3 & 4 & 3 & 3 & 32 & \\
\hline 3 & 3 & 2 & 4 & 3 & 4 & 3 & 3 & 3 & 3 & 4 & 32 & \\
\hline 4 & 3 & 3 & 4 & 3 & 3 & 3 & 3 & 3 & 3 & 3 & 31 & \\
\hline 5 & 4 & 3 & 4 & 4 & 3 & 3 & 4 & 3 & 4 & 3 & 35 & \\
\hline 6 & 3 & 4 & 4 & 4 & 4 & 3 & 4 & 4 & 4 & 3 & 37 & \\
\hline 7 & 3 & 3 & 3 & 4 & 4 & 4 & 4 & 4 & 4 & 4 & 37 & \\
\hline 8 & 3 & 3 & 4 & 4 & 3 & 3 & 3 & 3 & 3 & 3 & 32 & \\
\hline 9 & 3 & 3 & 4 & 4 & 3 & 4 & 3 & 4 & 4 & 4 & 36 & \\
\hline 10 & 4 & 3 & 4 & 4 & 4 & 3 & 3 & 4 & 4 & 4 & 37 & \\
\hline 11 & 3 & 4 & 4 & 3 & 3 & 3 & 4 & 3 & 3 & 3 & 33 & \\
\hline 12 & 3 & 3 & 4 & 4 & 4 & 3 & 4 & 4 & 4 & 4 & 37 & \\
\hline$\sum$ Score & 38 & 37 & 45 & 43 & 43 & 38 & 41 & 43 & 42 & 41 & 411 & \multirow{2}{*}{$71.35 \%$} \\
\hline Average & 3.17 & 3.08 & 3.75 & 3.58 & 3.58 & 3.17 & 3.42 & 3.58 & 3.5 & 3.42 & 34.25 & \\
\hline
\end{tabular}

The apparatus is also equipped with practicum manual that contain explanations of the apparatus components, experimental procedure guides, observation tables and student worksheets.

\section{CONCLUSION}

In this study, an apparatus has been produced to determine the coefficient of fluid viscosity using jetAudio Software and Subtitle Edit as an alternative learning media, as well as a solution to the limitations of practicum tools in Singkawang City secondary schools. From the results of the validation and user testing, it can be concluded that the apparatus is appropriate to use as learning media in physics learning.

\section{ACKNOWLEDGMENTS}

The authors would like to thank Directorate General of Research and Development Strengthening, Ministry of Research, Technology and Higher Education who has provided research grants with contract number: 619/L11/KM/2019. The authors also would like to thank STKIP Singkawang for supporting this research.

\section{REFERENCES}

[1] Koretsky, M., Kelly, C., \& Gummer, E. (2011). Student perceptions of learning in the laboratory: Comparison of industrially situated virtual laboratories to capstone physical laboratories. Journal of Engineering Education, 100(3): 540-573.

[2] Bair, S. (2013). Comments on "pressure-viscosity coefficient of vegetable oils" by Biresaw and Bantchev. Tribology Letters, 52(2): 351-353.

[3] Rosdianto, H., Sulistri, E., \& Daud, A. N. M. (2019). Determination of Fluid Viscosity Coefficient Using jetAudio and Subtitle Edit. JIPF (Jurnal Ilmu Pendidikan Fisika), 4(2): 83-90. 
[4] Hantoro, B., \& Suharno. (2014). Menyelidiki Hubungan Kecepatan Terminal Dan Viskositas Zat Cair dengan Video Analisis Tracker. Prosiding Pertemuan Ilmiah XXVIII HFI Jateng \& DIY, Yogyakarta, 26 April 2014: 35-37.

[5] Siddiqui, N., \& Ahmad, A. (2013). A study on viscosity, surface tension and volume flow rate of some edible and medicinal oils. Int. J. Sci. Environ. Technol, 2: 1318-1326.

[6] Shanti. M. R. S., (2014). Pembuatan Media Pembelajaran Pengukuran Viskositas Dengan Menggunakan Viskometer Dua Kumparan Dan Freewave3. Jurnal Pendidikan Fisika Indonesia, 10(1): 28-35.

[7] Mariani. F, et al. (2015). Penerapan Analisis Video Tracker dalam Pembelajaran Fisika SMA Untuk Menentukan Nilai Koefisien Viskositas Fluida. Prosiding Simposium Nasional Inovasi dan Pembelajaran Sains 2015 (SNIPS 2015): 333-336.

[8] Ramadhan, D., Serevina, V., \& Raihanati. (2016) Pengembangan Alat Praktikum Viskometer Metode Bola Jatuh Bebas Berbasis Sensor Efek Hall UGN3503 sebagai Media Pembelajaran Fisika. Prosiding Seminar Nasional Fisika (E-Journal) SNF2016, 5(1): 7-10.

[9] Vong, S. W., Yang, T., \& Zhu, C. (2003). Compressible Navier-Stokes equations with degenerate viscosity coefficient and vacuum (II). Journal of Differential Equations, 192(2): 475-501.

[10] Paredes, X., Fandiño, O., Pensado, A. S., Comuñas, M. J. P., \& Fernández, J. (2012). Pressureviscosity coefficients for polyalkylene glycol oils and other ester or ionic lubricants. Tribology Letters, 45(1): 89-100.

[11] Lei, Z., \& Lin, F. H. (2011). Global mild solutions of Navier-Stokes equations. Communications on Pure and Applied Mathematics, 64(9): 1297-1304.

[12] Mulyono, S., \& Agus, S. (2010). Kumpulan Software Pilihan Paling Dicari. MediaKita, 2008.

[13] Lynch, N. (2010). An excellent app to edit subtitles. 